\title{
RELATIONSHIP BETWEEN CRUDE OIL PRICES AND THE STOCK MARKET: BEFORE AND AFTER THE LIFTING OF U.S. CRUDE OIL EXPORT BAN
}

In-Jae Kim, Minnesota State University, Mankato, MN, U.S.A.

Kwang-il Choe, Minnesota State University, Mankato, MN, U.S.A.

\author{
dx.doi.org/10.18374/IJBR-20-1.2
}

\begin{abstract}
In this paper we study the relationship between crude oil prices and stock prices of oil-related companies in S\&P 500 both before and after the U.S. ban on crude oil exporting was lifted. We observe from the sample data that the stock prices are more sensitive to change in oil prices after the ban was lifted than before. Using linear regression models, we also identify a sub-industry of oil industry that is the most sensitive to change in oil prices and one that is the least sensitive to change in oil prices for both periods. Furthermore, the regression analysis shows that the stock returns of oil companies in S\&P 500 are more affected by S\&P 500 returns than oil returns.
\end{abstract}

Keywords: Oil Price, U.S. Oil Exporting Ban, S\&P 500, Stock Market, SOR Index 